\title{
Supervisory Support Key to Female Career Satisfaction
}

\section{Prof Paul Poisat}

Nelson Mandela Metropolitan University

Email: Paul.Poisat@nmmu.ac.za

Dr Michelle Mey

Nelson Mandela Metropolitan University

Email: Michelle.Mey@nmmu.ac.za

\section{Anthonie Theron}

Nelson Mandela Metropolitan University

Email: Anthonie.Theron2@nmmu.ac.za

\section{Doi:10.5901/mjss.2014.v5n10p11}

\begin{abstract}
This study examines the importance of supervisory support in light of current career-related barriers experienced by many South African women. Despite all the changes that have taken place since the abolishment of Apartheid, the latest statistics on workforce profiles and movements show that many barriers exist for countless South African women in reaching top management positions. Due to perceptions of unfairness and discriminatory tendencies, female employees may adopt a pessimistic attitude and become dissatisfied with their careers. Data were obtained from 75 females employed in various organisations in South Africa's Eastern Cape Province. Validated measures were combined into a single questionnaire that assessed career satisfaction, supervisory support, withdrawal behaviours, and organisational commitment. Descriptive and inferential statistics confirmed the crucial role of supervisory support in ensuring that female employees remain committed to their organisation, are satisfied with their careers, and do not withdraw psychologically and/or physically from their organisation. Organisations need to employ supportive organisational experiences and practices in order to ensure that their female employees remain committed to the organisation and do not engage in various psychological and physical withdrawal behaviours.
\end{abstract}

Keywords: supervisory support; organisational commitment; career satisfaction; turnover intentions; withdrawal behaviour

\section{Introduction}

The United Kingdom Equal Opportunity Commission estimated that it would take 65 years for women to reach equality with men as directors of Britain's top 100 companies (Smith, Crittenden and Caputi, 2012). The tendency for competent, highly educated women to drop out of the labour force has become an issue of concern to many organisations.

With the abolishment of Apartheid and the execution of extensive employment equity measures, there has, since 1994, been formal legislated equality between individuals of different races and genders in South Africa. While companies are under pressure to meet Employment Equity quotas (Booysen, 2007), recent findings outlined in the Employment Equity Commission's (EEC) Twelve (12 $\left.2^{\text {th }}\right)$ Annual Report (2012) revealed that white males still dominate top management positions. Kunyalala Maphisa, President of the Businesswomen's Association in South Africa (BWA) stated that a radical mind shift is needed in South Africa. This mind shift is needed if South Africa wants to shift gear from the slow, incremental changes in the number of women at executive levels, to a dramatic increase in the way women in corporate South Africa are perceived, promoted, and protected (Management Today, 2012).

According to the latest findings published in the BWA South African Women in Leadership Census 2012, women are clearly in a minority amongst their male counterparts, as only 12 women CEO's and 18 women Chairpersons were recorded in the census (Management Today, 2012). Against this background, many women reach a point in their career where no further advancement will be achieved. As a result, female employees may respond by engaging in withdrawal behaviours which manifest in the workplace in the form of absenteeism, lateness, burnout, and unhealthy employee turnover (Redmond and Newman, 2012). According to Miller and Wheeler (1992), the turnover rate of female employees 
is of concern as they have higher turnover rates.

Kiaye and Singh (2013) recently investigated the career-related barriers that female employees experience in various organisations located in Durban, South Africa. The results revealed that female employees experience a lack of respect from male colleagues, insensitive handling of the various roles played by women, and gender discrimination. Furthermore, family commitment and relocation also inhibited respondents' career growth (Kiaye and Singh, 2013). With the current career-related barriers that many South African women are experiencing in the workplace, this study aims to investigate the crucial role of supervisory support in ensuring that female employees are satisfied with their careers, remain committed to their organisations, and do not engage in destructive behaviour at work.

\section{Literature Review and Operationalisation of Variables}

The literature study provides a discussion of the dependent and independent variables displayed in the theoretical model (figure 1).

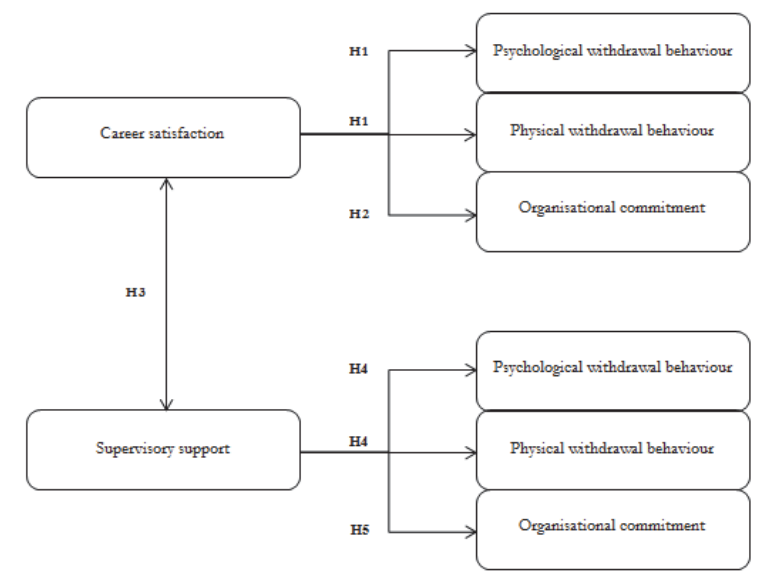

Figure 1. Research Model and Hypothesised Relationships

\subsection{Dependent Variables}

\subsubsection{Withdrawal Behaviour}

Employee turnover is a major concern in organisations. Nagadevara, Srinivasan and Valk (2008) explored the relationship between withdrawal behaviour and employee turnover for both male and female employees. The findings of the study clearly showed that withdrawal behaviours correlated positively with employee turnover intentions (Nagadevara, Srinivasan and Valk, 2008). It is not surprising that many female employees, frustrated in their efforts to advance in their careers, withdraw from their organisation (Stroh, Brett and Reilly, 1996). Salami (2010) investigated the relationship between career plateauing and job satisfaction, organisational commitment, and turnover intentions amongst female employees. A multiple regression analysis indicated that career plateauing positively correlated with turnover intentions (Salami, 2010).

Stroh, Brett and Reilly (1996) examined differential turnover rates between male and female employees employed by 20 Fortune 500 organisations. The results revealed that female managers' intentions to leave were predicted by perceptions of lack of career opportunity in their current organisation, job dissatisfaction and disloyalty to the current company (Stroh, Brett and Reilly, 1996). In another study by Miller and Wheeler (1992), gender differences in intentions to leave were examined. The study revealed that female employees were nearly twice as likely as male employees to report that they "definitely would" or "probably would" leave their organisations within two years. Opportunities for promotion were significant predictors of the intent to leave for female employees (Miller and Wheeler, 1992).

Against this background, the following is hypothesised:

H1: Career satisfaction is negatively associated with withdrawal behaviour.

\subsubsection{Organisational Commitment}

Organisational commitment is a physiological situation that binds the employee to his/her organisation (Meyer and Allen, 
1991). Committed employees internalise the organisation's goals, and are willing to continue to work in the organisation (Giritli, Sertyesilisik and Horman, 2013). Women are perceived as having lower levels of organisational commitment than men, as they often experience and display a different range of emotions to the majority of men in the workplace (Singh and Vinnicombe, 2000). As career-related barriers diminish female employees' chances of advancement and promotion to higher levels, it also slows down their interest and identification in the job (Singh, Gumber and Singh, 2010). As a result, their organisational commitment is negatively affected.

Given the above, the following is hypothesised:

H2: Career satisfaction is positively associated with female employees' level of organisational commitment.

\subsection{Independent Variables}

\subsubsection{Career Satisfaction}

The involvement of women in South African workplaces has been on the increase (Kiaye and Singh, 2013). The workforce population distribution outlined in the South African Quarterly Labour Force Survey is based on the Economically Active Population (EAP). The EAP includes individuals from 15 to 64 years of age who are either employed or unemployed, and who are actively seeking employment. Table 1 shows the national demographics of the EAP by race and gender. It is evident from Table 1 that the majority of males (54.6\%) are economically active, compared to females $(45.4 \%)$.

Table 1. Profile of the National Economically Active Population by Race and Gender (Adapted from the Employment Equity Commission, 2012)

\begin{tabular}{|l|c|c|l|c|}
\hline \multicolumn{4}{|c|}{ Economically Active Population } \\
\hline African male & $40.3 \%$ & & African female & $33.8 \%$ \\
\hline Coloured male & $5.9 \%$ & Coloured female & $5.2 \%$ \\
\hline Indian male & $1.8 \%$ & & Indian female & $1.1 \%$ \\
\hline White male & $6.6 \%$ & White female & $5.3 \%$ \\
\hline Foreign male & $0 \%$ & Foreign female & $0 \%$ \\
\hline \multicolumn{1}{|c|}{ Total } & $54.6 \%$ & & Total & $45.4 \%$ \\
\hline
\end{tabular}

With the influx of females into the labour market, together with the social, political and economic efforts to promote gender equity in the workplace, increasing numbers of women are starting to occupy leadership positions in South Africa (Booysen, 2007). However, according to top management workforce profiles, Table 2 shows that whites and males still dominate representation at top management level in terms of recruitment, promotion and skills development opportunities. It is evident that many career-related barriers exist for South African women in reaching top management positions.

Furthermore, while gender equity and affirmative action legislation have been implemented in South Africa, it is evident from table 2 that inequality in females' career progression still remains. Manning (1997) supports this by stating that women of all races are disadvantaged and a wasted resource. While more women are entering the workplace, long working hours and demanding job requirements are preventing them from holding seats at the boardroom table. Jamali, Safieddine and Daouk (2006) support this by stating that family responsibilities contribute to negative perceptions about women's priorities, and therefore limiting their chances of advancement. Many South African women reject career opportunities as they are still held responsible for their families and household work (Mathur-Helm, 2006). Organisations need to refrain from installing contradicting systems, as Meyerson and Fletcher (2000) found a number of organisations that provided employees with flexible working hours and childcare facilities to accommodate women, while still practicing a culture characterised by demanding and long working hours.

Against this background, women struggle to rise to senior positions and as a result, these individuals may not be satisfied with their career success, which is an internally generated and defined career outcome (Fields, 2002). Female employees who have been negatively affected by these barriers may feel that they have not made satisfactory progress toward their goals for income level, career advancement, and development. Barnett and Bradley (2007) investigated the impact of organisational support on career satisfaction. The results indicated a positive relationship between organisational support and employees' level of career satisfaction. Their study highlighted the need for organisations to invest in career development initiatives, as these practices may enhance career satisfaction.

Schwartz (1992) supports this by stating that organisations are paying various costs for failing to utilise and 
develop the talents of women to the fullest. These include loss of investment in training when female employees quit their jobs, career dissatisfaction and lowered performance because of their frustrations, opportunity costs resulting from unrealised potential, and failure to have the best talent represented at senior management levels (Schwartz, 1992).

Table 2. Workforce Profiles and Movements at the Top Management Level (Adapted from the Employment Equity Commission, 2012)

\begin{tabular}{|c|c|c|c|c|c|c|c|c|c|c|c|}
\hline \multirow{2}{*}{ Workforce Movements } & \multicolumn{4}{|c|}{ Male } & \multicolumn{4}{|c|}{ Female } & \multicolumn{2}{|c|}{ Foreign national } & \multirow{2}{*}{ Total } \\
\hline & African & Coloured & Indian & White & African & Coloured & Indian & White & Male & Female & \\
\hline \multirow{2}{*}{ Work force profile for all employers } & 2515 & 642 & 1146 & 10679 & 1060 & 285 & 303 & 1970 & 673 & 79 & 19352 \\
\hline & $13.0 \%$ & $3.3 \%$ & $5.9 \%$ & $55.2 \%$ & $5.5 \%$ & $1.5 \%$ & $1.6 \%$ & $10.2 \%$ & $3.5 \%$ & $0.4 \%$ & $100.0 \%$ \\
\hline \multirow{2}{*}{ Promotion for all employers } & 159 & 68 & 87 & 537 & 58 & 34 & 31 & 157 & 23 & 1 & 1155 \\
\hline & $13.8 \%$ & $5.9 \%$ & $7.5 \%$ & $46.5 \%$ & $5.0 \%$ & $2.9 \%$ & $2.7 \%$ & $13.6 \%$ & $2.0 \%$ & $0.1 \%$ & $100.0 \%$ \\
\hline \multirow{2}{*}{ Skills development for all employers } & 904 & 282 & 348 & 2729 & 422 & 126 & 128 & 700 & 0 & 0 & 5639 \\
\hline & $16.0 \%$ & $5.0 \%$ & $6.2 \%$ & $48.4 \%$ & $7.5 \%$ & $2.2 \%$ & $2.3 \%$ & $12.4 \%$ & $0 \%$ & $0 \%$ & $100.0 \%$ \\
\hline \multirow{2}{*}{ Recruitment for all employers } & 346 & 67 & 94 & 673 & 183 & 28 & 31 & 155 & 109 & 11 & 1697 \\
\hline & $20.4 \%$ & $3.9 \%$ & $5.5 \%$ & $39.7 \%$ & $10.8 \%$ & $1.6 \%$ & $1.8 \%$ & $9.1 \%$ & $6.4 \%$ & $0.6 \%$ & $100.0 \%$ \\
\hline
\end{tabular}

\subsubsection{Supervisory Support}

Supervisory career support is a key factor affecting an employee's career progression. Employees' careers are likely to be enhanced by supportive relationships with their supervisors (Wickramasinghe and Jayaweera, 2010). Supervisory support entails career enhancing functions such as providing challenging assignments, sponsorship, visibility, as well as psychosocial functions such as counselling, friendship and acceptance (Wickramasinghe and Jayaweera, 2010). Good supervisory feedback and constructive communication between an employee and his or her supervisor enhance the opportunity for advancement in the employee's capabilities (Van der Heijden, Kümmerling, Van Dam, Van Der Schoot, Estryn-Béhar and Hasselhorn, 2010). With regards to career satisfaction, Wickramasinghe and Jayaweera (2010) examined the effect of supervisory support on career satisfaction. The results revealed that supervisory career support significantly predicted career satisfaction (Wickramasinghe and Jayaweera, 2010). Van der Heijden et al. (2010) investigated the impact of social support upon intention to leave among female nurses. Their findings indicated that social support from one's direct supervisor appeared to contribute negatively to the intention to leave the nursing profession.

Based on the above reviewed literature, the following hypotheses are proposed:

H3: A lack of supervisory support reduces female employees' level of career satisfaction.

H4: A lack of supervisory support increases withdrawal behaviour.

H5: A lack of supervisory support reduces organisational commitment.

\section{Research Design and Method}

\subsection{Data Collection}

Before the research study was conducted, an ethical protocol was followed by obtaining ethics clearance from the Nelson Mandela Metropolitan University, South Africa (ethics number: H 13 BED HR 015). A total of 75 women working in a variety of organisations in the Eastern Cape Province of South Africa voluntarily completed an anonymous, self-report questionnaire. Several women's networks and three human resource managers were approached and asked to forward questionnaires to female colleagues, staff and friends. To be part of this study, respondents had to be female, be employed in a multi-level organisation, and be involved in some form of decision-making. A cover letter explaining the procedure and instructions to complete the questionnaires was attached. Furthermore, the cover letter stressed the voluntary and confidential nature of the research.

\subsection{Measuring Battery}

Validated measures from Greenhaus, Parasuraman and Wormley (1990); Lehman and Simpson (1992); and Mowday, Steers and Porter (1979) were combined into a single questionnaire. These measures will now be briefly discussed. 


\subsubsection{Career Satisfaction}

The questionnaire for the current study incorporated items that measured employees' satisfaction with their career success, which is an internally generated and defined career outcome (Fields, 2002). Responses were obtained on a five-point Likert scale ranging from "strongly disagree" (1) to "strongly agree" (5). This measure was developed by Greenhaus, Parasuraman and Wormley (1990), and also included items that focus on the extent to which an employee has made satisfactory progress towards goals for advancement, development of skills, and income level. Coefficient alphas ranged from 0.83 to 0.89 (Fields, 2002).

\subsubsection{Supervisory Support}

Supervisory support was measured by drawing on the work of Greenhaus, Parasuraman and Wormley (1990). This measure assesses employee perceptions of the extent to which they receive supervisory support in their job. Supervisory support may include career guidance, performance feedback, work opportunities that promote employee development and visibility, and challenging work assignments (Fields, 2002). Coefficient alpha for the entire measure was 0.93 (Fields, 2002). In terms of validity, supervisory support correlated positively with perceptions of acceptance, job discretion, employee promotability, and job performance in terms of both tasks and relationships (Greenhaus, Parasuraman and Wormley, 1990). Items were rated on a five-point Likert scale ranging from "strongly disagree" (1) to "strongly agree" (5).

\subsubsection{Withdrawal Behaviour}

The measure for the current study included items that describe psychological and physical withdrawal behaviours. The measure was developed by Lehman and Simpson (1992). Coefficient alpha values ranged from 0.70 to 0.84 for psychological withdrawal behaviours, and 0.58 for the physical withdrawal subscale. Psychological withdrawal behaviour correlated positively with turnover intentions (Fields, 2002). For both subscales, items were rated on a five-point Likert scale ranging from "strongly disagree" (1), to "strongly agree" (2).

\subsubsection{Organisational Commitment}

The Organisational Commitment Questionnaire (OCQ) was used to measure employees' level of organisational commitment. This widely used measure was originally developed by Mowday, Steers and Porter (1979) and uses 15 items to describe global organisational commitment (Fields, 2002). Coefficient alphas ranged from .81 to .93 (Fields, 2002).

\section{Data Analysis, Results and Discussion}

The Statistical Package for Social Sciences (SPSS Version 20) was used for statistical analyses (IBM, 2011). With regards to descriptive statistics, the major contributors to the mean scores are discussed. For inferential statistics, Pearson product-moment correlations were calculated in order to test the hypotheses. Furthermore, a multiple regression analysis was used to further investigate the relationships depicted in the hypotheses. The results are discussed in light of the research model (Figure 1).

\subsection{Reliability of Measurement Items}

For all measurement scales, standardised Cronbach's coefficient alpha was calculated. The internal consistency reliabilities of multiple item measures used in this study typically exceeded 0.70 , a level of reliability considered satisfactory for research purposes (Nunally, 1978). Table 3 presents this information.

Table 3. Cronbach's Coefficient Alpha $(n=75)$

\begin{tabular}{|l|l|c|c|}
\hline Code & Measuring instrument & Number of items & Cronbach's $\boldsymbol{\alpha}$ \\
\hline SB & Career satisfaction & 5 & 0.89 \\
\hline SC & Supervisory support & 9 & 0.97 \\
\hline SD (A) & Psychological withdrawal behaviours & 8 & 0.92 \\
\hline SD (B) & Physical withdrawal behaviours & 4 & 0.94 \\
\hline SE & Organisational commitment & 15 & 0.92 \\
\hline
\end{tabular}




\subsection{Descriptive Statistics}

The descriptive statistics were analysed with SPSS Version 20 (IBM, 2011). It was calculated that responses between 1 and 2.6 on the Likert scale would fall into the "Low" category; between 2.6 and 3.4 in the "Average" category; and between 3.4 and 5 in the "High" category.

Table 4. Frequency Distribution of the Demographic Variables of the Sample $(n=75)$

\begin{tabular}{|c|c|c|}
\hline Demographic variable & Frequency & Percentage \\
\hline \multicolumn{3}{|c|}{ RACE $(n=75)$} \\
\hline African & 40 & $53.3 \%$ \\
\hline Coloured & 10 & $13.3 \%$ \\
\hline Indian & 6 & $8 \%$ \\
\hline White & 16 & $21.3 \%$ \\
\hline Asian & 3 & $4 \%$ \\
\hline Total & 75 & $100 \%$ \\
\hline \multicolumn{3}{|c|}{ Home Language $(n=75)$} \\
\hline Afrikaans & 19 & $25.3 \%$ \\
\hline English & 34 & $45.3 \%$ \\
\hline Xhosa & 22 & $29.3 \%$ \\
\hline Total & 75 & $100 \%$ \\
\hline \multicolumn{3}{|c|}{ Age $(n=75)$} \\
\hline $20-29$ years & 18 & $24 \%$ \\
\hline $30-39$ years & 33 & $44 \%$ \\
\hline $40-49$ years & 21 & $28 \%$ \\
\hline $50+$ years & 3 & $4 \%$ \\
\hline Total & 75 & $100 \%$ \\
\hline \multicolumn{3}{|c|}{ Marital Status ( $n=75$ ) } \\
\hline Married & 47 & $62.7 \%$ \\
\hline Divorced & 7 & $9.3 \%$ \\
\hline Single & 21 & $28 \%$ \\
\hline Total & 75 & $100 \%$ \\
\hline \multicolumn{3}{|c|}{ Children $(n=75)$} \\
\hline Yes & 61 & $81.3 \%$ \\
\hline No & 14 & $18.7 \%$ \\
\hline Total & 75 & $100 \%$ \\
\hline
\end{tabular}

Table 4 lists the demographic variables of the sample. Five demographic variables were included in the questionnaire. The majority of the sample was African (53.3\%); English speakers (45.3\%); ranged between the ages of 30 - 39 years (44\%); married (62.7\%); and have children (81.3\%).

\subsubsection{Career Satisfaction}

Descriptive statistics for the variables of career satisfaction and supervisory support are show in Table 5 . It is evident from Table 5 that respondents are not satisfied with their careers. The majority of the sample (72\%) indicated that they are not satisfied with the progress they have made toward meeting their goals for income, where $43 \%$ of respondents feel dissatisfied with the success they have achieved in their career. Furthermore, the majority of respondents (53\%) indicated that they are not satisfied with the progress they have made toward meeting their goals for the development of new skills.

Table 5: Descriptive Analysis for Career Satisfaction and Supervisory Support $(n=75)$

\begin{tabular}{|l|l|l|l|}
\hline \multicolumn{1}{|c|}{ Variable } & Code & Mean & Sd \\
\hline Career Satisfaction & \multicolumn{2}{c|}{} \\
\hline I am satisfied with the success I have achieved in my career. & SB1 & 2.49 & 1.28 \\
\hline I am satisfied with the progress I have made toward meeting my overall career goals. & SB2 & 2.59 & 1.15 \\
\hline I am satisfied with the progress I have made toward meeting my goals for income. & SB3 & 2.00 & 1.23 \\
\hline I am satisfied with the progress I have made toward meeting my goals for advancement. & SB4 & 2.43 & 1.20 \\
\hline I am satisfied with the progress I have made toward meeting my goals for the development of new skills. & SB5 & 2.36 & 1.10 \\
\hline
\end{tabular}




\begin{tabular}{|l|l|l|l|}
\hline Supervisory Support & SC1 & 1.96 & 1.20 \\
\hline My supervisor takes the time to learn about my career goals and aspirations. & SC2 & 2.00 & 1.26 \\
\hline My supervisor cares about whether or not I achieve my goals. & SC3 & 1.99 & 1.08 \\
\hline My supervisor keeps me informed about different career opportunities for me in the organisation. & SC4 & 2.45 & 0.98 \\
\hline My supervisor makes sure I get the credit when I accomplish something substantial on the job. & SC5 & 1.96 & 1.20 \\
\hline My supervisor gives me helpful feedback about my performance. & SC6 & 2.00 & 1.24 \\
\hline My supervisor gives me helpful advice about improving my performance when I need it. & SC7 & 2.48 & 0.99 \\
\hline My supervisor supports my attempts to acquire additional training or education to further my career. & 2.09 & 1.04 \\
\hline My supervisor provides assignments that give me the opportunity to develop and strengthen new skills. & SC8 & 2.04 \\
\hline My supervisor assigns me special projects that increase my visibility in the organisation. & SC9 & 2.40 & 1.01 \\
\hline
\end{tabular}

\subsubsection{Supervisory Support}

There seems to be a lack of supervisory support. The majority of respondents indicated that their supervisor does not take the time to learn about their career goals and aspirations (61\%). With regards to career opportunities, another $61 \%$ indicated that their supervisor does not keep them informed about different career opportunities in their organisation.

For training and development opportunities, the majority of the sample (62\%) indicated that their supervisor does not support their attempts to acquire additional training or education to further their career.

\subsubsection{Withdrawal Behaviour}

Respondents indicated that they withdraw psychologically and physically from their organisations. Table 6 shows a summary of the items and responses related to psychological withdrawal behaviours. It is evident from Table 6 that in the past 12 months, the majority of respondents has left a work situation for unnecessary reasons (46\%), daydreamed (49\%), spent work time on personal matters (61.4\%), and let colleagues do their work for them (62.6\%).

Table 6. Summary of Items and Responses Related to Section D: Psychological Withdrawal Behaviours $(n=75)$

\begin{tabular}{|l|l|c|c|}
\hline In The Past Twelve Months, How Often Have You... & Response & Frequency & Percentage \\
\hline \multirow{5}{*}{ Left work for unnecessary reasons? } & Never & 21 & 28 \\
\cline { 2 - 4 } & Once or twice & 4 & 5.3 \\
\cline { 2 - 4 } & Sometimes & 4 & 5.3 \\
\cline { 2 - 4 } & Regularly & 44 & 58.7 \\
\cline { 2 - 4 } & Very often & 2 & 2.7 \\
\cline { 2 - 4 } & Total & 75 & $100 \%$ \\
\hline \multirow{5}{*}{ Daydreamed? } & Never & 9 & 12 \\
\hline & Once or twice & 9 & 12 \\
\cline { 2 - 4 } & Sometimes & 8 & 10.7 \\
\hline & Regularly & 48 & 64 \\
\hline \multirow{5}{*}{ Spent work time on personal matters? } & Very often & 1 & 1.3 \\
\cline { 2 - 4 } & Total & 75 & $100 \%$ \\
\hline \multirow{5}{*}{ Let others do your work? } & Never & 5 & 6.7 \\
\cline { 2 - 4 } & Once or twice & 14 & 18.7 \\
\cline { 2 - 4 } & Sometimes & 10 & 13.3 \\
\cline { 2 - 4 } & Regularly & 29 & 38.7 \\
\cline { 2 - 4 } & Very often & 17 & 22.7 \\
\cline { 2 - 4 } & Total & 75 & $100 \%$ \\
\hline & Never & 21 & 28 \\
\cline { 2 - 4 } & Once or twice & 6 & 8 \\
\cline { 2 - 4 } & Sometimes & 1 & 1.3 \\
\cline { 2 - 4 } & Regularly & 46 & 61.3 \\
\cline { 2 - 4 } & Very often & 1 & 1.3 \\
\cline { 2 - 4 } & Total & 75 & $100 \%$ \\
\hline
\end{tabular}

For physical withdrawal behaviours, the majority of the sample indicated that in the past year, they have:

- Left work early without permission (48\%);

- Taken longer lunch or rest breaks than allowed (66.7\%); 
- Taken supplies or equipment without permission (65.4\%); and

- Fallen asleep at work (64\%).

\subsubsection{Organisational Commitment}

Overall, respondents indicated a low level of organisational commitment. The majority of the sample indicated that they:

- Are not willing to put in a great deal of effort beyond that which is normally expected of them (68\%);

- Do not perceive their organisation as a great place to work for (88\%);

- Would not accept any types of job assignments in order to remain employed at their organisation (80\%);

- Their values are not congruent with their organisation's values (74.7\%); and

- Do not care about the fate of their organisation (64\%).

\subsection{Inferential Statistics}

\subsubsection{Hypotheses Testing}

Hypotheses were tested with correlations and a multiple regression analysis. All data were analysed using SPSS Version 20 (IBM. 2011). Table 7 shows the Pearson product-moment correlation coefficient for all the variables.

Table 7. Pearson Product-Moment Correlation Matrix for All Variables

\begin{tabular}{|c|c|c|c|c|c|}
\hline Variable & 1 & 2 & 3 & 4 & 5 \\
\hline 1. Career Satisfaction & & $0.793^{\star \star}$ & $-0.659 * \star$ & $-0.705^{\star \star}$ & $0.753^{\star \star}$ \\
\hline 2. Supervisory Support & $0.793^{\star \star}$ & & $-0.634^{\star \star}$ & $-0.668^{\star \star}$ & $0.736^{\star \star}$ \\
\hline 3. Psychological withdrawal & -0.659 ** & $-0.634^{\star \star}$ & & $0.929 * \star$ & $-0.611^{\star \star}$ \\
\hline 4. Physical withdrawal & $-0.705^{\star \star}$ & $-0.668^{\star *}$ & $0.929 * *$ & & $-0.681^{\star \star}$ \\
\hline 5. Organisational commitment & $0.753^{\star \star}$ & 0.736 ** & $-0.611^{\star *}$ & $-0.681^{* *}$ & \\
\hline
\end{tabular}

H1: Career satisfaction is negatively associated with withdrawal behaviour.

Hypothesis one ( $\mathrm{H} 1)$ is supported. An inverse relationship was found between career satisfaction and psychological withdrawal (-0.659), and physical withdrawal behaviour (-0.705). A multiple regression analysis (Table 8) confirmed an inverse relationship between career satisfaction and psychological withdrawal behaviour $(-0.420)$. The results propose that the more satisfied respondents are with their careers, the less likely they will withdraw psychologically from their organisation.

Table 8. Regression Summary for Dependent Variable: Psychological Withdrawal Behaviour

\begin{tabular}{|c|c|c|c|}
\hline Independent Variables & $\mathbf{b}^{*}$ & t-value & $\mathbf{p}$-value \\
\hline Career satisfaction & -0.420 & -2.973 & 0.004 \\
\hline Supervisory support & -0.301 & -2.129 & 0.037 \\
\hline $\mathrm{R}^{2}=0.467$ Significant effects are in bold.
\end{tabular}

For physical withdrawal behaviour, a multiple regression analysis (Table 9) also indicated an inverse relationship between career satisfaction and physical withdrawal behaviour $(-0.473)$.

Table 9. Regression Summary for Dependent Variable: Physical Withdrawal Behaviour

\begin{tabular}{|c|c|c|c|}
\hline Independent Variables & $\mathbf{b}^{*}$ & $\mathbf{t}$-value & $\mathbf{p}$-value \\
\hline Career satisfaction & -0.473 & -3.562 & 0.001 \\
\hline Supervisory support & -0.292 & -2.201 & 0.031 \\
\hline $\mathrm{R}^{2}=0.529$ Significant effects are in bold.
\end{tabular}

H2: Career satisfaction is positively associated with female employees' level of organisational commitment.

The results provide support for hypothesis two $(\mathrm{H} 2)$. A positive relationship was found between career satisfaction and organisational commitment (0.753). Furthermore, the regression analysis in Table 10 revealed a positive relationship between these two variables $(0.457)$. In other words, the findings suggest that the more satisfied female employees are 
with their careers, the more committed they will be to their organisations.

Table 10. Regression Summary for Dependent Variable: Organisational Commitment

\begin{tabular}{|c|c|c|c|}
\hline Independent variables & $\mathbf{b}^{*}$ & $\mathbf{t}$-value & $\mathbf{p}$-value \\
\hline Supervisory support & 0.374 & 3.128 & 0.003 \\
\hline Career satisfaction & 0.457 & 3.825 & 0.000 \\
\hline $\mathrm{R}^{2}=0.619$ Significant effects are in bold.
\end{tabular}

H3: A lack of supervisory support reduces female employees' level of career satisfaction.

Hypothesis three $(\mathrm{H} 3)$ is supported. A positive relationship was found between supervisory support and career satisfaction (0.793). Furthermore, the regression analysis in Table 11 also confirms a positive relationship between these two variables (0.793).

Table 11. Regression Analysis for Dependent Variable: Career Satisfaction

\begin{tabular}{|c|c|c|c|}
\hline Independent Variables & $\mathbf{b}^{\mathbf{*}}$ & $\mathbf{t}$-value & $\mathbf{p}$-value \\
\hline Supervisory support & $\mathbf{0 . 7 9 3}$ & 11.127 & 0.000 \\
\hline $\mathrm{R}^{2}=0.629$ Significant effects are in bold. \\
\hline
\end{tabular}

H4: A lack of supervisory support increases withdrawal behaviour.

The findings provide support for hypothesis four $(\mathrm{H} 4)$, as an inverse relationship was found between supervisory support and psychological withdrawal behaviour (-0.634), and physical withdrawal behaviour (-0.668). The regression analysis summarised in Table 8 also indicates an inverse relationship between supervisory support and psychological withdrawal behaviour (-0.301), and physical withdrawal behaviour $(-0.292)$.

H5: A lack of supervisory support reduces organisational commitment.

The findings provide support for hypothesis five (H5). A positive relationship was found between supervisory support and organisational commitment (0.736). Furthermore, the regression analysis summarised in Table 10 indicates a positive relationship between these two variables $(0.374)$.

\section{Conclusion, recommendations and implications for managers}

The purpose of the current study was to examine the importance of supervisory support in ensuring that female employees remain committed to their organisations, and prevent them from withdrawing either psychologically or physically from the organisation. As women make up more than half of South Africa's population, there is a huge scope for women to play a more significant role in leadership and decision-making in South African organisations. The low mean scores obtained for career satisfaction suggest that respondents are not satisfied with the progress they have made regarding income level, career advancement, and development. Inferential statistical analysis suggests that career dissatisfaction may increase withdrawal behaviour amongst employees, and negatively impact respondents' level of organisational commitment.

Furthermore, the results also suggest the crucial role of supervisory support in ensuring that female employees are satisfied with their careers, do not withdraw from the organisation, and remain committed and loyal to their employing organisations. Organisations can employ a variety of practices that support women's career advancement. Supervisors need to provide recognition, mentoring, coaching, and extensive training and development to support women's career advancement to ensure that they remain satisfied and committed. The results of the present study confirm the need for supervisors to learn about female employees' career goals and aspirations, keep them informed about different career opportunities within the organisation, and support respondents' attempts to further their careers by acquiring additional training.

The present study is not without limitations. Data were collected using self-report questionnaires raising the possibility that responses reflect a common method bias. Future research could include a larger sample from various sectors in order to confirm the generalizability of the findings. Despite these limitations, this study has provided evidence that relationships exist between female employees' career satisfaction, work attitudes, and the provision of supervisory support. 


\section{References}

Barnett, B.R. and Bradley, L. (2007). The impact of organisational support for career development on career satisfaction. Career Development International, 12(7), 617-636.

Booysen, L., (2007). Barriers to employment equity implementation and retention of blacks in management in South Africa. South African Journal of Labour Relations, 31(1), 47-71.

Employment Equity Commission (EEC), (2012). 12 th Annual Commission for Employment Equity Report. Pretoria: Department of Labour.

Fields, D.L., (2002). Taking the Measure of Work: A Guide to Validated Scales for Organizational Research and Diagnosis. Thousand Oaks: Sage Publications.

Giritli, H., Sertyesilisik, B. and Horman, B., (2013). An investigation into job satisfaction and organizational commitment of construction personnel. Global Advanced Research Journal of Social Sciences, 2(1), 1 - 11.

Greenhaus, J.H., Parasuraman, S. and Wormley, W.M., (1990). Effects of Race on Organizational Experience, Job Performance Evaluations, and Career Outcomes. The Academy of Management Journal, 33(1), 64-86.

IBM (2011). Statistical Package for Social Sciences, Version 20. [Online] Available: https://www.ibm.com/developerworks/ community/wikis/home?lang=en\#!/wiki/We70df3195ec8_4f95_9773_42e448fa9029/page/Downloads\%20for\%20IBM\%C2\%AE\% 20 SPSS\%C2\%AE\%20Statistics (June 20, 2013)

Jamali, D., Safieddine, A. and Daouk, M., (2006). The glass ceiling: some positive trends from the Lebanese banking sector. Women in Management Review, 21(8), 625-642.

Kiaye, R.E. and Singh, A.M., (2013). The glass ceiling: a perspective of women working in Durban. Gender in Management: An International Journal, 28(1), 28-42.

Lehman, W.E. and Simpson, D.D., (1992). Employee substance use and on-the-job behaviors. Journal of Applied Psychology, 77(3), 309-321.

Management Today (2012). BWA South African Women in Leadership Census 2012 [Online] Available: http://www.africanmanagers. org/sites/default/files/BWA\%20Aug12.pdf (January 14, 2014)

Manning, A.D., (1997). Radical Strategy. How South African companies can win against global competition. Sandton: Zebra Press.

Mathur-Helm, B., (2006). Women and the glass ceiling in South African banks: an illusion or reality? Women in Management Review, 21(4), 311-326.

Meyer, J.P. and Allen, N.J., (1991). A three-component conceptualization of organizational commitment. Human Resource Management Review, 1(1), 61-89.

Meyerson, D.E. and Fletcher, J.K., (2000). A Modest Manifesto for Shattering the Glass Ceiling. Harvard Business Review, 78(1), 126136.

Miller, J.G. and Wheeler, K.G., (1992). Unraveling the mysteries of gender differences in intentions to leave the organization. Journal of Organizational Behavior, 13(5), 465-478.

Mowday, R.T., Steers, R.M. and Porter, L.W., (1979). The measurement of organizational commitment. Journal of Vocational Behavior, 14(2), 224-247.

Nagadevara, V., Srinivasan, V. and Valk, R., (2008). Establishing a link between Employee Turnover and Withdrawal Behaviours: Application of Data Mining Techniques. Research and Practice in Human Resource Management, 16(2), 81-99.

Nunally, J. 1978. Psychometric Theory. 2nd ed. New York: McGraw-Hill.

Redmond, B.F., and Newman, T., (2012). Withdrawal Behaviours. [Online] Available: https://wikispaces.psu.edu/display/ PSYCH484/13.+Withdrawal+Behaviors (February 15, 2013)

Salami, S.O., (2010). Career Plateauing and Work Attitudes: Moderating Effects of Mentoring with Nigerian Employees. Journal of International Social Research, 3(11), 499-508.

Schwartz, F.N., (1992). Breaking with Tradition: Women and Work, the New Facts of Life. New York: Warner.

Singh, S., Gumber, V. and Singh, U., (2010). Glass ceiling, organisational commitment and well- being: A comparative study of women executives in Multinational Organisations (MNCs). Journal of Indian Academy of Applied Psychology, 41, 143 - 147.

Singh, V. and Vinnicombe, S., (2000). Gendered Meanings of Commitment from High Technology Engineering Managers in the United Kingdom and Sweden. Gender, Work \& Organization, 7(1), 1-19.

Smith, P., Crittenden, N. and Caputi, P., (2012). Measuring women's beliefs about glass ceilings: development of the Career Pathways Survey. Gender in Management: An International Journal, 27(2), 68-80.

Stroh, L.K., Brett, J.M. and Reilly, A.H., (1996). Family Structure, Glass Ceiling and Traditional Explanations for the Differential Rate of Turnover of Female and Male Managers. Journal of Vocational Behavior, 49(1), 99-118.

Van der Heijden, B.I.J.M., Kümmerling, A., Van Dam, K., Van der Schoot, E., Estryn-Béhar, M. and Hasselhorn, H.M., (2010). The impact of social support upon intention to leave among female nurses in Europe: Secondary analysis of data from the NEXT survey. International Journal of Nursing Studies, 47(4), 434-445.

Wickramasinghe, V. and Jayaweera, M., (2010). Impact of career plateau and supervisory support on career satisfaction: A study in offshore outsourced IT firms in Sri Lanka. Career Development International, 15(6), 544-561. 